\title{
Shariah Perspective on Marriage Contract and Practice in Contemporary Muslim Societies
}

\author{
Shamreeza Riaz
}

\begin{abstract}
Forced marriages are worldwide phenomena and also exist in Pakistani society. It involves the lack of free and full consent of at least one of the parties to a marriage. Mostly, females are victims of forced marriages. It is prevalent in the name of religion in many Muslim countries; however, it is purely a traditional and cultural phenomenon which has nothing to do with religion. Forced marriages are different from arranged marriages in which both parties freely consent to enter into marriage contract and they have no objection on the choice of partner selected by their parents. This study will highlights different forms of forced marriages in Pakistani society.
\end{abstract}

Index Terms-Child marriage, elements of marriage contract in islam, forced marriage, honor killings, marriage in shariah.

\section{INTRODUCTION}

New millennium is considered as the millennium of upholding the Human Rights throughout the world. Women are considered as most vulnerable human beings of the society due to violation of their basic and fundamental rights. Women rights gained so much importance and many organizations are working to provide them equal status in the society and to stop violence against them. Moreover, in every society gender equality is considered a powerful tool for empowering women, but in some states, this powerful tool is challenged by cultural and traditional norms. These norms sometimes become hurdle to provide women's basic rights and Pakistan is among those states. This work will highlight the existing practice of forced marriages in the contemporary societies which violates fundamental rights of women.

Marriage and family institution occupies a very pivotal position in the legal system of Islam [1]. It can be judged from the fact that Muslim jurists regarded the protection of marriage among the five fundamental objectives of Shariah. The Qur'an describes marriage as mithaqanghaliza. The phrase mithaqanghaliza implies that marriage is sacred and sanctified contract, which is higher in status than ordinary civil contracts. Marriage in Islam is essentially a righteous act and an act of devotion ('ibadah') [2]. Moreover, marriage is necessarily a civil contract; it has gained the same status as other contracts in society. However, it is not only a civil contract but also a sacred covenant (mithaq), which is having the sanctity of Shariah and pleasure of God. However, Muslim Jurists regard nikah or marriage to be

Manuscript received February 22, 2013; revised May 7, 2013.

Shamreeza Riaz is with the Department of Law, and Faculty of Shariah \& Law, International Islamic University, Islamabad, Pakistan (e-mail: shamreeza.riaz@iiu.edu.pk). both worldly affair (mu'amlh) and an act of worship (ibadah) at the same time.

These objectives of marriage contract cannot be achieved by forcing a woman to enter into marriage contract as Badlh-e-Sulh ${ }^{1}$; Sawara ${ }^{2}$ and Wanni ${ }^{3}$;such practices are against the Islamic provisions and rights granted by the Constitution of Pakistan. These are based on cultural and traditional norms.

The right to marry with free and full consent is clearly given by Islam and incorporated in national laws of the country. Moreover, it is established under international human rights law in many conventions such as Universal Declaration of Human Rights. However, in many Muslim states, it is crushed by customary and traditional practices practiced by many families. It shows the lack of religious knowledge, ineffectiveness of the law and inappropriate policies and procedures adopted by a state.

In order to know the perspective of society on forced marriages, I have examined few reported cases. Study of the reported cases reveals that forced marriage is not even considered a crime in many areas as it is commonly practiced in the name of religion. Many Muslim families think that Allah has given this right to parents to choose a life partner for their daughter. Moreover, they think that parents have been given all rights to decide any matter for their children. Many forced marriages are prevalent in the form of Badl-e-sulah, Sawara and Wanni and some girls are forced to enter into marriage contract on gunshot. Forced marriage of dual nationals by their parents is a contemporary issue which is debatable and need to be discussed here.

Some Pakistani families have dual nationalities and they bring their children back to Pakistan on holidays and force their daughters to get married in Pakistan to save the honor of their family. Such families are concerned about security of their children abroad and force them to get married in Pakistan at early age. Due to fear and insecurity of parents, the ratio of forced marriages among dual nationals is increasing day by day. Such marriages are based on cultural tradition but supported and linked with religion. Many objections from the West are raised on the legality of such marriages. Whereas, parents think that Islam has given them the right to decide future of their children and they can force their children to get married under this right. It is therefore necessary to see Shariah perspective on forced marriages.

${ }^{1}$ Badla-e-Sulh means giving a female in marriage contract or otherwise compelling her for marriage as a reconciliation of a family dispute.

${ }^{2}$ Sawar is a Pashto word denoting a child marriage custom in tribal areas of Pakistan and Afghanistan. This custom is tied to blood feuds among the different tribes and clans where the young girls are forcibly married to the members of different clans in order to resolve the feuds.

${ }^{3}$ Wanni is a child marriage custom in tribal areas of Pakistan. 


\section{Shariah Perspective on Marriage Contract}

Before Islam, women were treated as a 'commodity' that closely resembled a sale through which a woman became the property of her husband. Woman was given in marriage contract without her consent as a sale commodity. In ancient Arabia, a woman was subjected by males -her father, brother or close male relatives- when she was a virgin and her husband when she became a wife. A female had no voice in her marriage (in its initiation or its termination). Islam brought a shift in the basis of social foundation from blood kinship to fellowship in a community of believers [3].Classical family law as finally formulated was the product of Qur'ānic reform and customary practice. Islam discouraged all existing practices and provided equal rights to women.

The Holy Prophet (P.B.U.H) has emphasized on marriage in a large number of ahadith. Prophet (P.B.U.H) said on one occasion, "[m]arriage is my Sunnah", whoever turns away from my Sunnah, does not belong to me" [4]. This Hadith highlights the importance of marriage contract. An important purpose of marriage is to attain psychological, emotional and spiritual companionship [5]. This cannot be gained from forced marriage contract. Marriage helps men and women to lead a life of chastity; it secures them against immoral sexual indulgence and develops smooth relationship among a couple. However, in anti-women practices, women are given as blood money or compensation against a murder or dispute. She is insulted and taunted by her in laws. In such cases, it is impossible to achieve the basic purpose of marriage contract i.e., peace and harmony.

The Qur'ān calls marriage a his meaning"a castle" as it is protection against dishonesty and immodesty. It has frequently used the word muhsin ${ }^{5}$ and muhsanat ${ }^{6}$ which come from the root word hisn i.e. castle and fort [6]. Marriage safeguards and protects chastity in the same way as fort protects the garrison within from a besieging army [7]. These objectives of marriage can be achieved when the couple gets married with their own free consent. Islam endorsed rights of men and women equally and allowed them to choose their life partner with their consent. On the contrary, if a girl is given in Badla-e-Sulhas compensation of someone else's crime forcefully, that marriage contract would be an irregular marriage contract.

In such marriage contracts, husband does not accept his wife as a life partner. Moreover, in many cases, girls in early age are forced to sign marriage contract on gunpoint. A recently reported case showed that a 13 years old girl was forced on gunpoint to sign marriage contract in Taxila, near capital city Islamabad. The girl was recovered from illegal detention after forced marriage contract [8]. From such marriage contracts, pure intention and lasting love and affection cannot be achieved.

\section{ISLAM ENDORSES CONSENT MARRIAGE RATHER THAN FORCED MARRIAGE}

Marriage is necessarily a civil contract; it has gained the

\footnotetext{
${ }^{4}$ The term Sunnah in Arabic means way or practice chosen by the Holy Prophet (P.B.U.H) and recommended by him to be followed by Muslims.

${ }^{5}$ Muhsin means 'chaste man'.

${ }^{6}$ Muhsnat means 'chaste women'
}

same status as other contracts. However, it is not only a civil contract but also a sacred covenant (mithaq), which is having the sanctity of Shariahand pleasure of God.

Dr. MuhammedMunir described sanctity of marriage contract in following words:

Allah has created deepest love and solace among the married men and women for each other. The word dwell in tranquility with them (as mentioned in Qur'anic verse 30:21) connotes companionship and mutual love, which is distinct from mere sexual pleasure. Thus a wife in Islam is not handmaiden, but a lifelong companion of her husband, his consort [9].

This deepest love and solace cannot be achieved from a forced marriage contract whose purpose is to resolve any dispute where a girl is considered as a compensation of crime which she has not committed. For a valid marriage contract, consent of contracting parties is an essential element and without consent, it is considered irregular/fasid contract. However, marriage without consent is not only prevalent in rural but also in urban areas of Pakistan. Sometimes, if victim refused to enter into marriage contract without consent, her father, brother or other relatives killed her to preserve their honor. The Shalimar police reported on 8 May 2011 that Muhammad Asghar, resident of Lahore, gunned down his 22-year-old daughter Gull Afshan allegedly to preserve his honor when she rejected arranged marriage [10].

\section{ESSENTIAL ELEMENTS OF MARRIAGE CONTRACT IN SHARIAH}

Most of the families think that consent of the girl is not necessary for a marriage contract. They think it is the responsibility of parents to choose life partner for her. To clarify this view of Muslim families, there is a need to highlight main elements of marriage contract in Islam.

There are different views of Muslim jurists on the essential elements of marriage contract. According to Imam Shafi' $i$, marriage contract contains four essential requisites; offer and acceptance, contracting parties i.e. husband and wife, two witnesses and presence of guardian [11]. Imam Malik [12] added another element, dower, for valid marriage contract. According to him, guardian, dower, contracting parties and offer and acceptance are essential for valid marriage. Moreover, HanafiJurists just acknowledge one main element that is offer and acceptance [13].

The views of jurists showed that all have consensus on one element, offer and acceptance from both parties. It means that most necessary element of marriage contract is offer from one side and acceptance from the other. Usually, it happens that offer is done by the guardian of the bride who announces that his daughter is ready to marry and then ultimately groom declares his acceptance and then the marriage contract is concluded with the terms specified [14]. Here, it is very essential to differentiate that a forced marriage is different from an arranged marriage, which is an institution based on trust and consent. In Pakistan, arranged marriages are common and can be divided into two types; semi arranged marriage and fully arranged marriage. When the final decision is made by the couple and family agrees on their decision, it is called a semi arranged marriage; 
whereas, when the final decision is made by the parents and children have no objection, it is called a fully arranged marriage [15]. This concept is totally different from forced marriages prevalent in the name of religion.

According to Hanafi Jurists, no specific term is required for offer and acceptance, however, an expression which expresses the purpose of the parties clearly is sufficient. ${ }^{7}$ However, there are certain other terms such as qabiltu, raditu, tazawwajtu[16] etc. On the other hand, there is difference of opinion between Shafi' $i$ and Hambali jurists; they do not permit to convey offer from words other than ziwaj and nikah ${ }^{8}$, because according to them, these terms convey intention in clear and unequivocal terms.[17]

Qur'ān has also used such terms as, "Marry women of your choice two, or three or four" [18]. This verse clearly shows that a marriage contract cannot be valid until and unless it is with free mutual consent of both the parties.

These views of earlier Muslim scholars and verses of the Holy Qur'ān show that for valid offer and acceptance, there must be clear words from both parties to express their consent. Muslim Marriage contract provides a practical tool that allows couple to get married with their free consent. There is no place of forced marriages in Islam. Moreover, marriages with any conditions, such as marriage as compensation for dispute or to end enmity among the families, defeat the original purpose of marriage contract. Furthermore, marriage without consent is irregular marriage contract which can be terminated before consummation.

In Punjab, many forced marriages are carried out as a result of WattaSatta i.e., exchanging brides between two families. These marriage contracts are entered into with certain conditions such as, one marriage contract result would be another marriage contract, condition of waiving loan amount and in most cases, and blood money is waived through a marriage contract. Here, a very important question arises, whether or not these conditions are valid in marriage contract?

Opinion of Muslim Jurists is divided due to different views on the conditions that can be fixed by the parties and can be inserted in marriage contract. Hanafi and Maliki jurists divide conditions into valid and irregular conditions, however, their criteria varies [19]. ShafiJurists, like Malikis, also divide conditions into valid and void. According to them, valid conditions are permissible and are binding upon the parties whereas invalid conditions render the contract of marriage invalid [20]. Moreover, Hanbali Jurists define two conditions, one which are collateral to the contract and they entail some lawful advantage to one of the two contracting parties, for instance, a condition that the husband will not marry another women or he will not take her away from her hometown etc. Such conditions are binding on the parties. First three schools are restricted on the acceptability of extrinsic conditions and stipulations in marriage contract while the Hanbali School is liberal in this issue.

These arguments of four schools of thoughts show that only valid conditions can be inserted in marriage contract. A marriage contract cannot be considered a valid contract on the condition that another marriage will take place as a

\footnotetext{
${ }^{7}$ Words like ziwaj, nikah, hibah, bay etc. can be used.

${ }^{8}$ The legal contract between a bride and groom as part of an Islamic marriage; contract under Islamic marriage.
}

result of this contract as happens in WattaSatta $^{9}$. In WattaSatta tradition, most of the time sister of groom is forced to get married with the brother of bride to continue her own brother's marriage. For example, in order to continue a marriage of son, family forces their daughter to get married with brother of their daughter-in-law.

\section{Prevailing Practice of Forced Marriages}

Forced marriages are prevalent in Pakistani society especially in families that have double nationality and are residing in the West. Muslim immigrant communities in Europe have taken their tradition and cultural practices along with them and continue to practice their own culture [21]. Many daughters, sisters and cousins abroad are murdered in the name of honor.

In 2000, a young woman of Pakistani origin named Shahnaz was electrocuted by her brothers and mother in UK. The family had been living there for last thirty years and still continuing traditional practices. In 2003, SajidaBibi, a Pakistani woman from Birmingham wanted to marry someone against the wishes of her family. Her young male cousins stabbed her on her wedding day. The justice of the Crown Court in Birmingham sentenced the murderers to life imprisonment. The court further stated that 'those who live in our country should learn to respect the law of the land'.

It is also reported that many Pakistani families bring their daughters back to Pakistan and wed them in Pakistan either for nationality of male family member, or to save the honor of the family. Parents justify such forced marriages saying that if they do not wed girls in early age, they will rebel and get married in the residing country against the wishes of their parents.

Sameem Ali, 13 years old girl, residing in Britain, came to Pakistan along with her family for spending holidays. She was suddenly asked to wear red bride dress and forced to pronounce words after Imam. Her mother told her that she get married with a man twice her age whom she had seen only once at a family get-together in Pakistan [22]. She reported that "her mother told her that if she did not consummate the marriage, she would tie her to the bed, blindfold her and strip her, and then watch to make sure her daughter had sex with her husband". Further, she added, her husband told her that she was his wife and she had to sleep with him. When she tried to refuse and said that they needed to get to know each other first, he hit her. Such marriages are prevailing day by day in all Muslim families residing in foreign states.

In most forced marriage cases, female keeps silent to save the honor of her family. Very few cases are reported and in most of the reported cases, victim gets threat or physical danger from opposite family. Sadia, a 13 years old girl, was forced by her heroin addicted father and her brother-in-law to get married with an elderly man. She pleaded to High Court for her protection in 2010 and the court issued notice to the police on July 27 for her plea for protection. She was kidnapped by her brother-in-law with two persons from her house and they had fired rifle shots in the air to deter

\footnotetext{
${ }^{9}$ It means exchange marriage. In rural Pakistan, bride exchange, known as wattasatta (literally, 'give-take') is very common. It usually involves the simultaneous marriage of a brother-sister pair from two households.
} 
neighbors when she cried out for help. They kidnapped her to keep her away from the High Court and to force her to take back her case [23]. All these practices show that women are suffering not only in rural and tribal areas of Pakistan but also in urban areas. They are forced to get married with stranger person and in some cases with a person who is double their age. Such practices, though contrary to Islamic teachings, are endorsed by cultural and traditional customs. There is a need to amend laws to stop such violations against women.

Moreover, in Muslim societies, women are not given a chance to choose their husband. If they get married with their own consent, they are condemned and even murdered in some cases in the name of honor of family. This part will examine landmark decisions of judiciary to discourage honor killings and granting a right to get married with free and full consent. Moreover, it will examine certain cases and the impact of these decisions.

In 2002, Supreme Court passed a verdict and declared all honor killing as grave violation of human rights under the Constitution of Pakistan. In Muhammad Akram Khan case, the Court ruled that:

Legally and morally speaking, nobody has any right nor can anybody be allowed to take law in his own hands to take the life of anybody in the name of 'Ghairat' 10. Neither the law of the land nor religion permits so-called honor killing which amounts to murder (Qatl-i-Amd) simpliciter. Such iniquitous and vile act is violative of fundamental right as enshrined in Chapter 1 of the Constitution of Islamic Republic of Pakistan which provides that no person would be deprived of life or liberty except in accordance with law and any custom or usage in that respect is void under article 8 (1) of the Constitution [24].

In another similar case, Kamal Shah and The State, the Supreme Court, in 2008, relied on many cases and passed a rule that punishment would not be of lesser amount on the ground of murder in the name of honor [25]. In Muhammad Saleem V. The State, the Supreme Court discouraged family honor killing, [26] but on mitigating circumstances, death penalty was reduced to imprisonment to life.

In Saima Waheed Case, majority of judges (2/3) ruled that the consent of Wali is not necessary for a valid marriage contract [27]. But a single judge ruled that without the consent of Wali, marriage contract would be invalid. After the establishment of Federal Shariat Court, the issue of consent marriage was discussed in the light of Muhammad Imtiaz v. The State [28], ArifHussain and AzraParveen v. The State [29], Muhammad Ramdan v.The State [30] and Muhammad Yaqoob v.The State [31]. Federal ShariatCourt passed a verdict that the consent of Wali is not necessary for the validity of Nikah. It is necessary to mention here that the decisions of the Federal Shariat Court are binding on the High Courts and all courts subordinate to High Court [32]. Supreme Court passed the same verdict in Mauj Ali v. Syed Safdar Hussain Shah [33]. Under Article189 of the Constitution of Pakistan, decisions of Supreme Court will be

\footnotetext{
${ }^{10}$ According to Pashtons, "Ghairat" means zeal. To keep on one's own and his tribe's prestige, one has to be zealous, courageous and somewhat heedless. The one who is not zealous and courageous may come under the chapaw of others
}

binding on High Courts and courts subordinate to High Court and under Article 203D and 203F, any decision of the Court, Federal Shariat, in the exercise of its jurisdiction under this Chapter shall be binding on a High Court and on all courts subordinate to a High Court

These remarkable decisions of Superior Judiciary showed that women rights are always protected by Pakistani Courts. The ratio of anti-women practices such as Wanni, Sawara, child marriage and forced marriage are increasing day by day. The deep study of these practices showed that all these practices are carried out without the consent of women. If the girls get married with a guy, with their consent, they are declared as kari $^{11}$ by jirga ${ }^{12}$. They are murdered in the name of honor. Moreover, they are forced to get married with the aggrieved family (which is normally hostile) to compensate blood money or as a punishment of crime committed by their brothers, father or other family members. They are, mostly in rural areas, forced to get married in early age. Most horribly, to save the property of family, they are forced to marry with the Holy Qur'ān. Unfortunately, in rural and tribal areas of Pakistan, all such practices are carried out in the name of religion.

The main purpose of this study was to highlight antiwomen practices, to distinguish whether such practices were taught by religion or motivated by cultural beliefs. Further, this study was carried out to see whether the rulings of superior judiciary are pro-women or anti-women and to highlight some legal guarantees provided by Pakistani legislation.

\section{LEGISLATION ON FORCED MARRIAGE IN PAKISTAN}

In Pakistan, many marriages are performed under duress and without the free and full consent or informed consent of both parties [34]. Islamic law, Constitution of Pakistan and other legislations do not allow forced marriages. For valid marriage contract, it must be registered under chapter 5 of Muslim Family Law Ordinance 1961[35]. However, in some parts of Pakistan, a written nikahnama, marriage contract, is misunderstood as insulting the credibility or honor of the other family.

Under this ordinance, Muslim women and men must register their nikah with nikah registrar of the concerned council and both, bride and groom, can obtain a copy of nikahnama. The registration of marriage contract is compulsory to know the consent of both parties. Unfortunately, mostly marriages in Pakistan are not registered properly.

To stop forced marriages in Pakistan, a new section 310A was inserted in PPC by Criminal Law Amendment Act 2004 but this section did not prohibit forced marriage completely. In 2011, a new Act, entitled Prevention of Anti-women

\footnotetext{
${ }^{11}$ Karokariis a compound word. Literally karo means "black male" and kari means "black female", A metaphoric term for adulterer and adulteress. Being so labelled leads more often than not to the murder of both man and woman allegedly guilty of having an illicit affair. This is especially true in the rural areas of the southern province of Sindh. In other parts of the country, women are more likely to be accused of sexual improprieties and murdered in order to wash the sullied family honour

${ }^{12}$ A local term used to define group of people/elders who sit together for resolving a dispute. It is normally used in Balochistan, NWFP, FATA, PATA.
} 
Practices, was passed which inserted a new section, 498B in PPC. This section prohibits forced marriage and criminals are liable to punishment for ten years or a prescribed term accordingly, which must not be less than three years. Moreover, they may be liable for fine of 500,000 rupees.

The marriage of a girl under the age of sixteen and of a boy under the age of eighteen is called a child marriage and it is an offence/crime under the Child Marriage Restraint Act, 1929 [36]. Furthermore, after the enactment of Protection of Women Act 2006, it is a crime punishable under section 498B of PPC. Justice can be enforced only when law of land is implemented wholly and legal provisions are equally applicable on all individuals.

\section{CONCLUSION}

After a profound study of scholarly work, views of Muslim scholars, verses of the Qur'anand Hadith, case study of existing practices, and landmark decisions of the Supreme Court, High Courts and Federal Shariat Court, it can be concluded that:

Firstly, all reported cases of Wanni, Sawara and Badlah$e$-sulahrevealed that these cases are encouraged by society at large. The innocent minor girls are forced to get married before reaching age of puberty. They are considered as cattle and not even given a right to live their early life with their parents. They are treated inhumanely, tortured and insulted by their in laws. Islam has given a right to resend marriage contract at the age of puberty. However, reported cases revealed that if girls raise their voice against such marriage after age of puberty, they are silenced forever by their family members in the name of honor.

Secondly, Islam endorses the concept of consent marriage rather forced marriage. Our judiciary has also passed landmark pro-women decisions in this regard but still most of the girls are forced to get married with their parents' consent. It is very concerned issue for dual status nationals. Many girls, who have dual nationality, are facing this problem. This issue needs further research.

Fourthly, the Holy Prophet (PBUH) encouraged Muslims to marry in many Ahadith. He (P.B.U.H) made it obligatory on all persons who are able to work, support a wife and children. It is also essential for the procreation of naslwhich is one of the Maqasid(purposes) of Shariah. It is a point to ponder how Islam can endorse marriage with the Holy Qur'an. Forced marriage is a very heinous crime which snatches many fundamental rights.

\section{REFERENCES}

[1] M. T. Mansoori, Family Law in Islam, Islamabad: Shariah Academy, International Islamic University, vol. 5, 2009.

[2] M. T. Mansoori, Family Law in Islam, Islamabad: Shariah Academy, International Islamic University, vol. 5, 2009.

[3] J. L. Esposito, Women in Muslim Family Law, New York: Syracuse University Press, vol. 15, 1982.

[4] S. Bukhari, Hadit, no. 5063, Hadith, no. 4776, "Sahih Muslim," Hadith, no, 1020.

[5] M. T. Mansoori, Family Law in Islam, Islamabad: Shariah Academy, International Islamic University, vol. 7, 2009.

[6] M. T. Mansoori, Family Law in Islam, Islamabad: Shariah Academy, International Islamic University, vol. 7, 2009.

[7] N. F. Umar, "Women in Islam: A discourage in rights and obligations," Trans. Saleeha Mahmood Abedin, Cairo: International Committee for Women and Child, vol. 38, 1999.
[8] Four Booked, Dawn News, Islamabad, 2011.

[9] M. Munir, Marriage in Islam: A Civil Contract or a Sarosanct? Hamdard-Islamicus, vol. 30, no. 1, January-March 2008.

[10] Girl Who Rejected Arranged Marriage Silenced, Dawn News, Lahore, May 9, 2011.

[11] Ramli, Nihayat al-Muhtaj, vol. 6, pp. 207.

[12] Dardiri, Al-Shariah al-Kbir, vol. 2, pp. 222.

[13] Kasani, Bada'I al-Sanai, vol. 2, pp. 229.

[14] M. T. Mansoori, Family Law in Islam, Islamabad: Shariah Academy, International Islamic University, vol. 32, 2009.

[15] M. Haq. Arranged Marriages a Tradition in Pakistan, Three Generations of Women Share Their Experiences, the Epoch Time, [Online]. Available: http://www.theepochtimes.com/n2/world/arranged-marriages-inpakistan-persist-4983.html

[16] M. T. Mansoori, Family Law in Islam, Islamabad: Shariah Academy, International Islamic University, vol. 5, 2009

[17] Al Muhadhdhab, vol. 2, no. 41, Kasshf al-Qina, vol. 5, no. 37; alMughni, vol. 6, pp 532.

[18] Al Quran, vol. 4, no. 3.

[19] I. Abidin, Al-Durr al-Mukhtar, vol. 2, pp. 405.

[20] Shirbini, Mughni Al-Muhtaj Shirbini, Cairo: Sharikahwa Matba'ah Mustaf al-Babi-al-Halabi, 1993, vol. 3, pp. 226

[21] T. S. Khan, Beyond Honor: A Historical Materialist Explanation Of Honor Related Violence, Oxford University Press, Pakistan, 2006, at 21.

[22] S. Reid, The modern slave trade: taken on holiday and forced to wed a stranger. Daily Mail. [Online]. Available: http://www.dailymail.co.uk/femail/article-2062425/Forced-marriagesModern-slave-trade-8k-British-girls-year-forced-wed-will.html

[23] R. Tanveer, Fugitive From Forced Marriage Kidnaped, July 26, 2011.

[24] A. K. V. Muhammad, The State, PLD 2002 SC 96.

[25] K. Shah and 2 V, The State, 2009, P Cr. L J 547, Lahore.

[26] S. V Muhammad. The State, PLD 2002 SC 558.

[27] H. A. V. Waheed, AsmaJehangir, Appeal, no.98, 1997.

[28] I. V. Muhammad, The State, PLD 1981 FSC 308.

[29] A. Hussain and A. V. Parveen, "The State," PLD 1982 FSC 42.

[30] R. V. Muhammad, "The State," PLD 1984 FSC 93.

[31] Y. V. Muhammad, "The State," 1985 PCr.LJ 1064.

[32] M. Muhammad, "The rights of women and role of superior judiciary in pakistan with special reference to family law cases from $2004-$ 2008," pp. 281.

[33] A. V. Mauj, Syed Safdar Hussain Shah 1970 SCMR 437.

[34] Facets of Violence against Women Gender Justice and Protection Project, United Nations Development Program Pakistan, 2009.

[35] Article 5. Muslim Family Law Ordinance 1961. [Online]. Available: http://www.ahmedandqazi.com/actsandregulations/familyLaw/musli mFamilyLawsOrdinance1961.pdf

[36] Article 2(a). Child Marriage Restraint Act 1929. [Online]. Available: http://pakistan.childrightsdesk.com/?p=1094

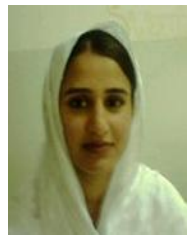

Shamreeza Riaz was born in Pakistan on December 13, 1985. Now she is a member of IIUI, Pakistan. In 2009 , she completed her LL.B and in 2012, she completed LL.M Human Rights Law with distinction from the same university. She is doing $\mathrm{PhD}$ law from the same University.

In January 2011, she joined Department of Law in the the International Islamic University Islamabad as a regular faculty member. Presently she is working as RESEARCH ASSOCIATE at Faculty of Shariah\& Law, International Islamic University, Islamabad. She is Editorial Assistant of 'Islamabad Law Review', a research journal of Faculty of Shariah \& Law.

She has 6 published articles and one book with Edwin Mellen Press on final publishing stage. Her many articles are accepted or under process in 2013. Her recent research includes, An Analytical Study Revisiting Debate on Interpretation of Article 38 of the Statute of International Court of Justice, International Law and Policy Review, Volume 1 Issue 2, 2011

Transformation of Extradition To Rendition: A Critical Legal History, HamdardIslamicus No.2 issue of theBaital-Hikmah 2013.

Expulsion of Afghan Refugees from Pakistan: A Violation of Principle of Non-Refoulement, International Journal of Terrorism and Political Hot Spots, Volume 6 Issue 3, 201

Ms. Riaz is legal advisor at Student World Assembly, U.K and member of Youth for Human Rights, U.K. She is Reviewer of Journal of Literature and Art Studies, USA. In 2011, she received research grant from International Islamic University Islamabad and in 2012, she was awarded travel grant for international Conference by Higher Education Commission. 